\title{
Impact of Tax Incentives and Foreign Direct Investment on Manufacturing Companies in Nigeria
}

\author{
1*Benjamin Musa Bweseh \\ MSc Banking and Finance: Department of Accounting and Finance \\ University of Agriculture Makurdi, Nigeria \\ 2*Munura Maihankali \\ Chevening Scholar; MSc Data Science: School of Computing, \\ Robert Gordon University Aberdeen, United Kingdom \\ $3^{*}$ Kefas Rimamnuskeb Galadima \\ BSc Computer Science: Department of Computer Science, \\ Federal University Wukari, Nigeria
}

\begin{abstract}
The paper focuses on the impact of Tax Incentives (TI) and Foreign Direct Investment (FDI) on manufacturing companies in Nigeria, the paper used structured questionnaires in collection of data; 325 copies questionnaire. Both descriptive and inferential analyses were used in data analysis, the descriptive statistics revealed that the FDI, Tax Holidays (TH), Custom Duties Exempted (CDE) have mean values of 0.2140, 0.6667 and 0.9290 respectively and transparency, political stability have the mean scores of 2.5 and 4.5454 respectively which indicates that the political stability of Nigeria is good. The Pearson's correlation result implies that none of the explanatory variables is significantly correlated with the dependent variable. Breusch-Pagan/Cook-Weisberg test is used which gives the chi-square value and its probability at $5 \%$ significance level which specifies that the model for FDI is significant at the 0.05 level with a p-value of 0.0002 and Crosssection Dependence Test shows that cross-sectional dependence is not an issue since the probability of the FDI model is greater than the threshold $\mathbf{p}>\mathbf{0 . 0 5}$. Wooldridge test is utilized in determining autocorrelation in the idiosyncratic error term in the panel-data model. The result of pooled Ordinary Least Square Regression is presented alongside the result of DriscollKraay. Conclusion was made that TIs have a significant positive effect on FDI inflow into the Nigerian economy. The recommendations are made that: Nigerian government should maintain the elegant of TH alongside CDE and Government should intensify means of ensuring that the impact of TIs on FDI extends to agricultural sectors so as to gain more value and continuously re-invest the profit with a view to enhancing the capital base of FDI inflow.
\end{abstract}

\section{Keywords: Tax Incentive, Foreign Direct Investment, Manufacturing Companies, Tax Custom Duties}

\section{INTRODUCTION}

Taxation is fundamental to sustainable development and the growth of emerging economies especially where natural resources are relatively scarce. Tax incentives (TIs) are basically designed to attract new investment and to expend existing ones in priori industries which is based on the country development plan capable of stimulating economy growth. The globalization process has led to the emergence of new issues such as technological changes and innovation necessitating the need to attract Foreign Direct Investment (FDI) to complement local efforts. Not only have companies tended to become more mobile, but also governments have to deal with this new dimension in the design of their national tax policy on TI in order to attract FDI. An increasing number of governments compete hard to attract multinational companies as FDI using TIs; this trend seems to have grown considerably as evidenced by the number of high profile FDI in Nigeria oil and gas sector (Morisset and Pirnia 1999).

Morisset (2003) notes that TIs approach has had mixed results and have been contested by OECD countries and multilateral organisations because they have often been associated with suspicious capital flows. FDI is a potential source of funding for developing and developed nations. Strategies of attracting FDI turned out to be a heavily used approach of many governments across the world to boost their economies. The rationale behind the granting of TIs is to exploit investment opportunities, where the tax system is seen as obstacle (Michael, 2016) TIs are used to improve social welfare of the community; they can also be used to discourage certain activities which aim is to grant incentives to promote stock market performance (Ondabu, Willy and Kisaka, 2016). The use of TI has generated considerable debate about whether governments have offered unreasonably large incentives to entice those firms to invest in their countries. Taxes affect the Net Return on Capital (NRC) and should influence the capital movements between countries. Morisset and Pirnia (1999) observed that the elimination of barriers to capital movements have stimulated governments to compete for FDI in global markets as well as reinforced the role of tax policy in this process. Oloyede (2002) state that the dual-gap analysis provides the framework, which shows that the development of nation is a function of investment and that such investment that requires domestic savings is not sufficient to ensure that development take place. Soludo (2003) opined that countries borrow for reasons such as macroeconomic reason to both finance higher investment and circumvent hard budget constraints, which have effect on the development of a nation. Several international and regional development institutions have been advocating the importance of FDI in the development of developing countries for decades despite few countries can remain competitive without FDI with the potential benefits including technology transfer, employment gains, skills upgrading, and growth. Arogundade (2005) Posit that TIs policy in Nigeria decorated the statute books for so long without anybody undertaking a survey to determine their effectiveness or continued relevance. The inadequacy and non -availability of the companies' access to the spare parts and raw materials constituted the major factors towards the decline in the growth rate of the 
manufacturing sector after 1981 (Dipak and Ata, 2003). Aganga (2014) aver that Nigerian manufacturing sector appeared to be gradually bouncing back to reckoning based on the achievements recorded in the sector in the on-going year and the federal government kicked off an industrial revolution in the year 2012 to strategically empower and position the nation's manufacturing sector as the key driver of the economic growth through increased contribution to Gross Domestic Product (GDP) and Nigeria recorded 8.9billion dollars investment inflow in 2013, making Nigeria the number one investment destination in Africa. Therefore, TIs can have positive effect if implemented and planned properly; attract investment to a country, increased employment, higher number of investment transfers, research and technology development, and improvement to less developed areas and negative impacts on an economy if they are not properly designed and implemented. Typically a cost to TIs comprises: resource allocation, compliance, revenue and corruption costs. The imperative of balance of payment (BOP), GDP, and external debt service ratio are combined to make injection of FDI a sine qua non for economic recovery and development. Aganga (2014), if Nigeria is going to migrate from a poor nation to rich country, the key is industrialization. Studies carried out in Nigeria on TIs and FDI of listed manufacturing companies virtually received less attention a result of this attempt to fill the gap in literature by examining TIs and FDI in manufacturing companies of Nigeria shall be made whose challenges has lead Nigeria as a nation to elsewhere, The proxies are TH, CDE, TI administration for the period of ten years to 2018.

\section{LITERATURE REVIEW \\ Conceptual Framework}

\subsection{Foreign Direct Investment (FDI)}

Omankhanlen (2011), FDI is an investment made by an investor or enterprises in another enterprise or equivalent in voting power or other means of control in another country with the aim to manage the investment and maximize profit. FDI serves as an important engine for growth in developing countries through two modes of action: expanding capital stocks in host countries and bringing employment, managerial skills, and technology. Macaulay (2011) states that FDI is an investment made to acquire a lasting management interest in a business enterprise operating in a country other than that of the investor. FDI is an integral part of an open and effective international economic system and a major catalyst to development. Adeleke, Olowe and Fasesin (2014) opined FDI is an investment into production or business in a country by an individual or company of another country, either by buying a company in the target country or by expanding operations of an existing business in that country, which is in contrast to portfolio investment and passive investment in the securities of another country such as stocks and bonds. World Bank (1996) posit that FDI as investment is made to acquire a lasting management interest in an enterprise and operating in a country other than that of the investors. FDI includes mergers and acquisitions, building new facilities, reinvesting profits earned from overseas operations and intra company loans. Aseidu (2004) noted that natural resources and market size are the chief determinants of FDI in Africa and FDI inflow to Africa can be promoted by political and macroeconomic stability, by educated labor force, less corruption and efficient legal system. Lall (2002) revealed that privatization was adopted to encourage foreign investment (FI) in Nigeria, which involves transfer of state-owned enterprises, companies that are completely or partly owned by or managed by private individuals or companies. Shiro (2009) submits that the Federal Government of Nigeria (FGN) has taken a number of measures necessary to woo foreign investors into Nigeria. These measures include the repeal of laws that are inimical to FI growth, promulgation of investment laws, various oversea trips for image laundry by the President. It can be analysed in terms of inflow of new equity capital, re- invested earning, trade and supplier's credit, net inflow of borrowing and other obligations from the parent company or its affiliates (Nwankwo et al, 2013). Olopoenia (1985) FI is seen as an additional factor of production and supplement to the national savings effort of the capital importing country. According to Agada and Okpe (2012) FDI is an attempt by individuals, groups, companies and government of a nation to move resources of productive purpose across its country to another country with the anticipation of earning some surplus. FDI emerged as the most important source of external resource flows to developing countries over the years and has become a significant part of capital formation in these countries, though their share in the global distribution of FDI continue to remain small or even declining (Otepola 2012).

\subsection{Tax Incentives (TIs)}

Tax incentives (TI) are fiscal measures that are used to attract local or foreign investment capital to certain economic activities or particular areas in a country. Zee, Stotsky and Ley (2002) posited that any tax provision that is applicable to all investment projects does not constitute a tax incentive; excludes general tax incentives such as accelerated depreciation that applies to all investments. General tax provisions deserve to be called incentives for three reasons: they are designed as such and function as such; it makes sense for a government to broadcast that it is offering attractive TI for investment even if they take the form of general rather than selective provisions of the tax code and a number of countries, such as Indonesia and Uganda, have shifted from selective to general incentives, all with the intention of stimulating investments. Tax incentive has over the years taken different directional approaches, which are considered as a tool that is used to accelerate economic growth and even development (Olaleye, 2016). Fletcher (2002) observes that TI as those special exclusions, exemptions or deductions, from income tax liability, offered to taxpayers by the government as an enticement or encouragement to engage in specified activities. Ifueko (2009) noted that TI as special arrangements in the tax laws to; attract, retain or increase investment in a particular sector, stimulate growth in specific areas and assist companies or individuals carrying on identified activities. Governments have constantly used the TI laws as a policy instrument for increasing investment in certain economic sector and overcoming challenges posed by unfavorable investment conditions. Among the TI usually utilized in Nigeria are company income taxes (CIT), capital allowances, value added tax (VAT), capital gains tax reliefs, double taxation treaty and $\mathrm{TH}$. Taxation performs an important function in economy policy by generating income for governments to finance public services, increase productivity, improve the overall quality of life of the people, enhance investment climates and facilitate growth. Section (8) of CITA (2004), taxes are payable as specified upon profit of any company accruing in, derived from, brought into, or received in Nigeria in respect of, among others, any trade or business for whatever period of time the trade or 
business may have been carried out. Taxation comes in form of Personal Income Tax (PIT), CIT, Capital Gain Tax (CGT), Education Tax (ET), Petroleum Profit Tax (PPT), VAT etc. According to CITA (2004), CIT is a tax payable for each year of assessment on the profit of any company, a rate of 30\%, these include profit accruing in, derived from or brought into or received from a trade, business or investment. Companies with turnover of less than 1 million naira are taxed at a low rate of $20 \%$ for the first five years of operation if they are into manufacturing. Some of the efforts of the government to create a conducive environment for FDI in Nigeria are such that loans granted to Nigerian companies may be exempted from tax where the required conditions are met, Nigerian companies with a minimum of $25 \%$ foreign equity and within their first four years of operation are exempted from payment of minimum tax, TH granted to a firm as a tax -free status for a certain period of time.

\section{Customs Duty Exemptions (CDEs)}

Customs duty is a tariff on goods when transported across international borders which is to protect country's economy, residents, jobs, environment, etc., by controlling the flow of goods, especially restrictive and prohibited goods, into and out of the country which has a rate in percentage. The percentage is determined by the total purchased value of article paid at a foreign country and not based on factors such as quality, size, or weight. The Harmonized Tariff System (HTS) provides duty rates for virtually every existing item. Custom and Border Protection (CBP) uses HTS Schedule which is a reference manual that provides the applicable tariff rates and statistical categories for all merchandise import.

\subsection{Tax Holiday (TH)}

Tax holidays are implemented for businesses to encourage financial activity and foster growth, it is used in the hope of increasing the GDP in developing countries, Governments attract foreign investors or foreign companies that set up base in the host country, it is often put in place in particular industries to help promote growth, develop, or diversify domestic industries. The government loses out on revenues that would have been generated from sales during the temporary tax-break periods, it increase tax revenue over the long term because they help businesses stay in business or grow, creating more taxable revenue for the tax authority, the lost revenue offset by the increased purchases of trade looking to take advantage of the tax break. The increased sales during a TH are preceded by reduced sales before the holiday; thus, the TH shifted sales that would have happened before or after the holiday to the holiday dates. Since retailers do not pay sales tax out-of-pocket some retailers may unethically take advantage of TH by increasing the prices of the goods and reducing consumer savings.

\subsection{Manufacturing companies in Nigeria}

The impact of manufacturing industry in any economic development cannot be overemphasized. Few countries have been able to grow their wealth without investing in the manufacturing industry. A strong and thriving manufacturing sector usually precipitates in industrialization. The history of industrial development and manufacturing in Nigeria has been marred with a series of policy inconsistencies and distractions attributable to the discovery of oil. Despite the challenges that beset the Nigerian manufacturing industry, it has witnessed good growth in recent years. Manufacturing industries in Nigeria have done well in the production of goods for the nation's population as well as for export. Government has highlighted initiatives to boost manufacturing in Nigeria via the provision of incentives to support industrial hubs, Review local fiscal and regulatory incentives to support the development of industrial cities, parks and clusters, Rationalize tariffs and waivers on the equipment and machinery imports required for agro-industry. Lack of funds and an enabling environment for industrialists have denied the nation the capacity to achieve significant industrial growth and development or industrialization which Nigeria has always hoped and craved for. Considering the enormous importance attached to industrialization and how it impacts on our economy, any problem militating against its achievement should be of interest to us. The Construction sector is very crucial in any nation's social and economic development with respect to employment generation; the various activities undertaken in the sector are very germane to fostering effective sectorial linkages. The agricultural sector has contributed the most (about 27\%) to this expansion relative to Oil \& Gas (1.4\%), Financials (3.3\%), Manufacturing $(9.0 \%)$ and Trade $(18.8 \%)$.

\subsection{Empirical Review}

Olaleye, Riro, and Memba, (2016) examined CIT incentives on FDI in Listed Nigerian Manufacturing Companies, The findings showed strong positive linear relationships between reduced company income TI and FDI. Adeleke, Olewe and Fasesin (2014) investigated FDI on Nigeria's economic growth for the period of 1999 to 2013, the result revealed that economic growth is directly related to inflow of FDI and statistical significant at 5\% level, it implies that a good performance of the economy is a positive signal for inflow of FDI. Abubakar, Haruna and Ahmed (2012), examined Nigerian Investment Promotion council (NIPC) in attracting FDI in Nigeria. Findings reveal a significant correlation between the establishment of NIPC and an increase in FDI inflow and the average value of FDI inflows prior to the establishment differed from the one after the establishment and lastly revealed that NIPC had succeeded in influencing the growth of FDI in Nigeria. Simret (2013) analyzed the effectiveness of tax incentive in attracting FDI in Ethiopia. Dummy variables were used to indicate the presence and absence of TI, TH and CDE in the ten sectors under consideration for the period from 1992 to 2012. Econometric models that include TH, CDE and control variables were used in the analysis. The empirical result shows that only TH was found significant while CDE is insignificant and indicates that tax incentive sensitivity of FDI depends on the sector to which the investment is flowing. Barlow and Wenders (1995) surveyed TI on FDI of 247 US companies on their strategies to invest abroad. The result of the survey showed that together TI (10\%) and host country's government encouragement to investors (11\%) made up $21 \%$ of the responses ranked fourth place behind determinants such as currency convertibility, host country political stability and guarantee against expropriation. Econometric studies carried out on the bivariate relationship between FDI and TI seem to confirm the above survey that though tax considerations are important in the 
decision of foreign investors to invest in any host economy; it however, do not carry as much weight as market and political factors and in some cases TI were found to have little or no effect on the locations of FDI.

Agodo (1978) examined tax concession of FDI using 33 US firms having 46 manufacturing investment in 20 African countries. The result showed that TI were found to be insignificant determinant of FDI both in simple and multiple regressions. Wells and Allen (2001) presented case against incentives, consistent result with the above findings which is based on Indonesian experience where TH were offered for foreign investors and then dropped. It was found that FI continued to grow even after the TH were dropped proving the negligible role of TI in attracting FDI. This could be a strong case against incentive schemes as it has showed an actual natural experiment outcome. Hassett and Hubbard (2002) discovered that investment incentives create significant distortions by encouraging inefficient investment and that low inflation is the best investment incentives than TI. The study shows specifically that FDI is affected by tax rates with a $10 \%$ point increase in corporate income tax rate lowering FDI by $0.45 \%$ point of GDP.

Walid (2010) examined the economic and financial risks on FDI on macro level from 1997-2007 using multiple linear regression models. The result revealed that there exists significant and positive relationship between FDI and economic and financial variables utilized for the study. The study recommended promotion of FDI via TI to attract new investments. Significant to the present study is the empirical analysis conducted by Babatunde and Adepeju (2012) to determine the impact of TI on FDI in the oil and gas sector in Nigeria using data for 21 years. Using Karl Pearson coefficient correlation statistical method of analysis, it was found that there is a significant impact of TI on FDI in the oil and gas sector. Also, found that the major determinants of FDI in Nigeria are openness to trade and availability of natural resources on FDI. Sulaiman and Azeez (2012) studied external debt on the economic growth of Nigeria using GDP as the endogenous variable measuring economic growth as a function of ratio of external debt to export, inflate on and exchange rate (EXRAT) proxy as the exogenous variable for the period from 1970 to 2010, the result shows that external debt has contributed positively to Nigeria economy and a similar research was done by Iya, Gabdo, and Aminu (2013) with the same result.

Dickson and Presley (2013), study on TI and revenue productivity of the Nigerian tax system from 1981 to 2009 periods in order to identify the short-run performance of various taxes. The study concludes that the report on total tax revenue buoyancy calls for serious attention and policy challenge, considering the enormous importance of generating resources and less dependence on external borrowing to facilitating economic growth and development. This can however be tackled by adopting sound policies that will reduce or eliminate the corruption prevalent in the tax system coupled with the inefficiency rocking the system. Similarly, Bora (2013) studies the responsiveness of FDI to tax in Ethiopia which covers ten sectors; the study found out that tax incentive is sensitive but depends on the sector applied. Kimberley (2009) conducted studies which focus on the relationship between TI and FDI composition and analysed how TI can affect the composition of FDI in different countries; the result indicates that TI is only effective in affecting FDI composition in high-tech industries as well as capital-intensive sectors such as finance sector.

Millio, Azimeb and Gollagori (2016) examined the relationship between FDI flows and tax revenues in Ethiopia both at aggregate and disaggregate tax revenue levels such as income tax, corporate tax, trade tax and business profit tax. The results suggest that both FDI and GDP had negative impact on the aggregate tax revenue both in the short-run and long-run. At disaggregated tax revenue components level mixed results have been observed.

George and Bariyima (2015) studied TI and FDI in Nigeria. The result shows that FDI response to TI is negatively significant, that is, increase in TI does not bring about a corresponding increase in FDI. The study recommends that dependence on TI should be reduced and more attention be put on other incentives strategies such as stable economic reforms and stable political climate. Ezera (2016) analysed customs duty incentives on customs revenue mobilization for the period 2009 to 2014 in Zimbabwe. The results from the two separate models confirm that customs duty incentives had negative effects on customs revenues. Andabai (2014) examined the determinants of public policies and the manufacturing sector in Nigeria using 17years time series data spanning for period 1997-2013. The result shows that, there is a negative significant relationship between excise duty, and capacity utilization. There is also a negative significant relationship between employment rate and capacity utilization. The study also reveals a positive significant relationship between lending rate and capacity utilization.

Uwubanmwen and Ogiemudia (2006) examined FDI on economic growth in Nigeria, Employing the Error Correction Model (ECM), annual secondary time series data covering the period of 1979 to 2013 using an ECM technique to determine the short-run and long-run effect of FDI on economic growth of Nigeria. Granger causality methodology was used to analyse and establish the nature of relationship between FDI and economic growth in Nigeria. Empirical analysis reveals that FDI has both immediate and time lag effect on Nigerian economy in the short-run and FDI has a non-significant negative effect on the Nigerian economy in the long-run during the period under review. Thus, FDI has a significant positive effect on the growth as well as the development of the Nigerian economy only in the short run during the period under review. Tea (2010) examined the role and importance of FDI in Georgia after transition period and its' impact on economic growth of the country and also analysed ways for attracting FDI. It focuses on effectiveness of investment climate in Georgia after transition period and on analysis of results of global crisis on Georgia's investment. Despite the improvement of the investment climate in Georgia, there still remain a number of persistent problems on which FDI cannot maximize its impact. Main tendencies of improving investment climate and economic growth of the country are considered. Ehijiele, Sunday and Nuruddeen (2016) investigated FDI on the manufacturing sector in Nigeria. The result suggests a positive and significant relationship between EXRAT and manufacturing output (MOUTPUT) in Nigeria and the recommendations proposed that government should step-up efforts in attracting FDI into the sector by ensuring that investor confidence is protected and also that despite the fact that the importance of FDI cannot be over accentuated, there is the need for government and policy makers to realize the fact that the fundamental element in any successful development strategy ought to be the encouragement of domestic investors first before going after foreign investors. 


\section{Theoretical Framework}

The internalisation theory was developed by Buckley and Casson in 1976 and then by Hennart, in 1982 and Casson, in 1983. Initially, the theory was launched by Coase in 1937 in a national context and Hymer in 1976 in an international context. This theory tries to explain the growth of international companies and their motivations for achieving FDI. Hymer, thus identifies two major determinants of FDI: removal of competition and the advantages which some firms possess in a particular activity. The result meant the same conclusion: transnational companies face some adjustment costs when the investments are made abroad. Hymer recognized that FDI is a firm-level strategy decision rather than a capital-market financial decision.

Production cycle theory developed by Vernon in 1966 was used to explain certain types of FDI made by U.S. companies in Western Europe after the Second World War in the manufacturing industry which believes that there are four stages of production cycle: innovation, growth, maturity and decline (Vintila 2010). Thus, if in the first stage of the production cycle, manufacturers have an advantage by possessing new technologies, as the product develops also the technology becomes known.

The eclectic theory developed by professor Dunning is a mix of three different theories of FDI (O-L-I); Ownership advantages: Monopoly advantages in the form of privileged access to markets, Technology and Economies of large size; Location: The economic benefits of quantitative and qualitative factors of production and costs, Political advantage, Social advantages; Internalisation: Supposing the first two conditions are met, it must be profitable for the company the use of these advantages, in collaboration with at least some factors outside the country of origin( Dunning and Lunda 2008). The characteristics of the eclectic paradigm OLI offers a framework for assessing different ways in which the company will exploit its powers from the sale of goods and services to various agreements that might be signed between the companies (Dunning 2000).

Capital theory was developed on premise that FDI mad by MNCs in other countries was to receive higher return on the capital invested. This position was confirmed by a study conducted by Mundell (1960) where empirical evidence showed how US firm realized higher return on capital invested over and above European investment in home countries.

\subsection{METHODOLOGY}

Survey research designs and ex-post facto were adopted with population of 74 listed manufacturing companies and 325 questionnaires to the staff of various companies in Nigeria. Multiple regression and one-way analysis of variance were utilized to test the hypothesis; FDI is measure as a function of TI thus:

$\mathrm{FDI}=\beta_{0}+\beta_{1} \mathrm{TH}_{\mathrm{it}}+\beta_{2} \mathrm{CDE}_{\mathrm{it}}+\beta_{3} \mathrm{~T}_{\mathrm{it}}+\beta_{4} \mathrm{PS}_{\mathrm{it}}+\mathrm{e}_{\mathrm{it}}$

Where: FDI=Foreign direct investment $\mathrm{TH}=$ Tax holidays

CDE $=$ Custom duties exemptions $\mathrm{T}=$ Transparency

PS = Political Stability $\quad \beta_{0}=$ Regression intercept

$\mathrm{P}_{1}, \mathrm{P}_{2}=$ Parameters to be estimated $\mathrm{e}=$ Error term

\subsection{RESULTS AND DISCUSSIONS}

\section{Descriptive Statistics}

The result of the descriptive statistics involving the mean, minimum, maximum, standard deviation, skewness and kurtosis of the variables is presented.

Table 1: Descriptive Statistics

\begin{tabular}{lcccccc}
\hline Variables & Mean & Std. Dev. & Min. & Max. & Skewness & Kurtosis \\
\hline FDI & 0.2140 & 0.31 & 0.0005 & 1.4302 & 1.23 & 6.3 \\
Tax Holiday & 0.6667 & 0.48 & 0 & 1.0000 & -0.71 & 1.50 \\
Custom Du_Exe & 0.9290 & 0.30 & 0.2570 & 1.2980 & -0.83 & 2.95 \\
Transparency & 2.5000 & 0.24 & 2.0000 & 2.9000 & -0.43 & 2.72 \\
Political Stability & 4.5454 & 0.51 & 4.0000 & 5.0000 & -0.18 & 1.03 \\
\hline
\end{tabular}

Note:FDI=Foreign Direct Investment; Custom Du_Exe=Custom Duties Exempted

The result of descriptive statistics in table 1 shows the FDI mean value of 0.2140 depicts that on the average, the value of FDI accruing to the economy through the period is two hundred and fourteen million naira while the maximum is one billion, four hundred and thirty million. It shows also that TH with the mean value of 0.6667 portrays that $66.67 \%$ of the sectors covers in this study enjoys TH. Moreover, CDE have an average score of 0.9290 . Control variables; transparency has the mean score of 2.5 which portrays that it is at the lower ebb, political stability has a mean value of 4.5454 which indicates that the political stability of Nigeria is good.

\subsection{Correlation Analysis}

The relationship is seen as small where $r= \pm 0.30$ to \pm 0.49 and where $r \geq 0.50$ the relationship strength is thought to be substantial. Pearson correlation analysis was carried out to determine the extent and direction of the relationship between the study variables. 
Table 2: Correlation Matrix (Obs=33)

\begin{tabular}{|c|c|c|c|c|c|}
\hline Variable & 1 & 2 & 3 & 4 & 5 \\
\hline 1. FDI & 1 & & & & \\
\hline 2. Tax Holiday & 0.187 & 1 & & & \\
\hline 3. Custom Du_Exe & 0.2391 & -0.1402 & 1 & & \\
\hline 4. Transparency & 0.1223 & 0.0267 & $0.3941 * *$ & 1 & \\
\hline 5. Political Stability & -0.1897 & 0.1291 & -0.1911 & -0.1514 & 1 \\
\hline
\end{tabular}

Note: $* *=$ significant at the 0.05 level. FDI=Foreign Direct Investment

From the Pearson's correlation result presented in table.2, none of the explanatory variables is significantly correlated with the dependent variable. Explicitly, TH has a positive but insignificantly related to FDI ( $r=0.187)$. Moreover, CDE is positively and insignificantly associated with FDI with correlation coefficient value of 0.2391 . Transparency has an insignificant positive association with FDI ( $\mathrm{r}=0.1223)$, while political stability is negative and insignificantly associated with FDI ( $r=-0.1897)$. Equally important, there is no issue of multicollinearity among the independent variables since they have correlation coefficients below 0.80

\subsubsection{Homoscedasticity Test}

Breusch-Pagan/Cook-Weisberg test is used which gives the chi-square value and its probability at $5 \%$ significance level.

Table 3: Breusch-Pagan/Cook-Weisberg Test

\begin{tabular}{llll}
\hline Dependent variable & Chi2 $(1)$ & Prob > Chi2 & Null (Ho) \\
\hline FDI & 14.05 & 0.0002 & Rejected \\
\hline
\end{tabular}

Note: Ho (null): Homoscedasticity. FDI=Foreign Direct Investment

Table 3 specifies that the model for FDI is significant at the 0.05 level with a $p$-value of 0.0002 . The result indicates that the variance is widely spread which needs to be corrected. The problem of heteroscedasticity that appeared in the FDI model is handling with Driscoll-Kraay Standard Errors Regression

\section{Cross-section Dependence Test}

The test is required to check for contemporaneous correlation, the Pesaran's CD test was employed. Table 4 shows that crosssectional dependence is not an issue since the probability of the FDI model is greater than the threshold $p>0.05$.

Table 4: Pesaran's CD (Cross-section Dependence) Test

\begin{tabular}{lll}
\hline Variables & Pesaran's test of Cross-sectional Independence & Av. Absolute value of off-diagonal element \\
\hline FDI & $-1.013, \mathrm{Pr}=0.3110$ & 0.5976 \\
\hline
\end{tabular}

\section{Serial Correlation Test}

Drucker (2003) Wooldridge test is utilized in determining autocorrelation in the idiosyncratic error term in the panel-data model.

Table 5: Wooldridge Test

\begin{tabular}{lccc}
\hline Variables & F $(1,2)$ & Prob > F & Ho (null) hypothesis \\
\hline FDI & 21.826 & 0.0429 & Rejected \\
\hline
\end{tabular}

Notes: H0: No first order autocorrelation.

Based on the result Wooldridge test of serial correlation presented above, the regression model suffers from serial correlation problem because it has a significant $\mathrm{p}$-value $(\mathrm{p}<0.05)$. The problem of serial correlation inherited for the FDI model is handled using the Driscoll-Kraay Standard Errors Regression as suggested.

\section{Discussion of Driscoll-Kraay Regression Result}

The result of pooled Ordinary Least Square Regression is also presented alongside the result of Driscoll-Kraay as delineated. 
Table 6: Result of Pooled OLS and Driscoll-Kraay Standard Errors Regression

\begin{tabular}{lcccccc}
\hline & \multicolumn{3}{c}{ Pooled OLS } & \multicolumn{3}{c}{ Driscoll-Kraay } \\
\hline Variables & $\mathrm{B}$ & $\mathrm{t}-$ stat. & $\mathrm{p}>\mathrm{t}$ & $\mathrm{B}$ & $\mathrm{t}$-stat. & $\mathrm{p}>\mathrm{t}$ \\
\hline Intercept & 0.3507 & 0.43 & 0.668 & 0.3506 & 2.25 & $0.048^{* *}$ \\
Tax Holiday & 0.1578 & 1.36 & 0.186 & 0.1578 & 3.99 & $0.003^{* * *}$ \\
Custom Duties Exemption & 0.2436 & 1.24 & 0.225 & 0.2436 & 5.61 & $0.000^{* * *}$ \\
Transparency & 0.0082 & 0.03 & 0.973 & 0.0082 & 0.24 & 0.817 \\
Political Stability & -0.1075 & -0.97 & 0.342 & -0.1075 & -3.80 & $0.003^{* * *}$ \\
\hline Observations & & 33 & & Observations & 33 \\
F $(4,28)$ & & 1.10 & & Group & 3 \\
Prob $>\mathrm{F}$ & & 0.3744 & & $\mathrm{~F}(4,10)$ & 11.62 \\
$\mathrm{R}^{2}$ & & 0.1362 & & Prob $>\mathrm{F}$ & $0.0009^{* * *}$ \\
Adj. $\mathrm{R}^{2}$ & & 0.0128 & & $\mathrm{R}^{2}$ & 0.1362 \\
\hline
\end{tabular}

Note: $* *$ and $* * *$ imply statistical significant on the 5 and $10 \%$ level, respectively

The OLS regression result in table 6 , shows that $\mathrm{R}^{2}$ has a value of 0.1362 indicating the variations in FDI which is influenced by the explanatory variables with the F-value of 4,$28 ; 1.10$ and a probability value of 0.3744 , the OLS model is said to have no goodness-of-fit. TH and CDE have a positive, but insignificant effect on FDI with beta coefficients $(\beta)$ of 0.1578 and 0.2436 respectively. Transparency also has an insignificant positive effect on FDI $(\beta=0.0082)$, whereas, political stability has insignificant negative effect on FDI $(\beta=-0.1075)$.

Driscoll-Kraay Standard Errors regression result in table 6 shows that the model has an $\mathrm{R}^{2}$ value of 0.1362 which portrays that the explanatory variables explain $13.62 \%$ of the variations in FDI. The model is significant based on $\mathrm{F}(4,10) ; p<0.01$, and indicating the validity and goodness-of-fit of the model utilized, The regression result from table 6 demonstrates that TH has a significant positive effect on FDI at $5 \%$ statistical significance level $(\beta=0.1578, p<0.05)$.

The regression result from table 6 portrays that CDE has a significant positive impact on FDI at $1 \%$ statistical significance level $(\beta=0.2436, p<0.01)$ which means that an increase in CDE by $1 \%$ would result in an increase in FDI by $24.36 \%$, or an increase in CDE by 1 would leads to an increase in FDI by 0.2436 (N24.360 billion) as in the study of Bora (2013), Kimberley (2009), and Olaleye et al. (2016) but in disagreement with the findings of George and Bariyima (2015), and Millio et al. (2016).

Transparency has a positive, but insignificant effect on FDI $(\beta=0.0082, p>0.10)$; Political Stability has a significant negative effect on FDI at $1 \%$ statistical significance level $(\beta=-0.1075, p<0.01)$, indicating that an increase in political stability would result to a decrease in FDI. However, this result is odd but is in line with the findings of George and Bariyima (2015) and Ezra (2016).

\section{Robustness Test}

Table 7: Driscoll-Kraay Standard Errors Regression for three groups

\begin{tabular}{|c|c|c|c|c|c|c|}
\hline \multirow[t]{2}{*}{ Variables } & \multicolumn{2}{|c|}{ Manufacturing sector } & \multicolumn{2}{|c|}{$\begin{array}{l}\text { Agricultural } \\
\text { sector }\end{array}$} & \multicolumn{2}{|c|}{$\begin{array}{l}\text { Construction } \\
\text { Sector }\end{array}$} \\
\hline & Coef. & $t$-stat & Coef. & $t$-stat & Coef. & $t$-stat \\
\hline Constant & 0.7637 & $1.89 *$ & 0.0989 & 0.94 & 0.4330 & $1.744^{*}$ \\
\hline Tax Holiday & 0.4277 & $2.79 * *$ & -0.0005 & -0.01 & 0.0844 & $3.44 * * *$ \\
\hline Custom Du_Exe & 0.6374 & $4.01 * * *$ & 0.0937 & $1.47 *$ & 0.1685 & $4.79 * * *$ \\
\hline Transparency & 0.1415 & 0.71 & -0.0271 & -0.31 & -0.2032 & $-4.94 * * *$ \\
\hline Political Stability & -0.3318 & $-5.33 * * *$ & -0.0108 & -0.21 & -0.0163 & -0.43 \\
\hline Observations & 11 & & 11 & & 11 & \\
\hline Groups & 1 & & 1 & & 1 & \\
\hline $\mathrm{F}(4,10)$ & 12.28 & & 4.11 & & 48.45 & \\
\hline Prob $>$ F & 0.0007 & & 0.0319 & & 0.0000 & \\
\hline $\mathrm{R}^{2}$ & 0.5776 & & 0.1783 & & 0.5116 & \\
\hline
\end{tabular}

Note: *,**, and *** implies statistical significance on 10, 5, and $1 \%$ level, respectively.

The result is said to be fit and valid since the probability values under the three sectors are significant. Explicitly, the model is significant at $1 \%$ level under manufacturing and construction sectors, while $5 \%$ under agricultural sector. Moreover, the $\mathrm{R}^{2}$ values are $0.5776,0.1783$, and 0.5116 for manufacturing, agricultural, and construction sectors respectively.

The result from table 7 depicts that TH has a significant positive effect on FDI at $10 \%$ and $5 \%$ under manufacturing $(\beta=0.7637$; $p<0.10)$ and construction sectors $(\beta=0.04330 ; p<0.05)$. However, TH is found to have an insignificant positive effect on FDI under the agricultural sector $(\beta=0.0989 ; p>0.10)$. Further, CDE has a significant positive effect on FDI at $1 \%$ significance under manufacturing $(\beta=0.6374 ; p<0.05)$ and construction $(\beta=0.1685 ; p<0.10)$ sectors respectively and $10 \%$ statistical significance under agricultural sector.

Transparency has an insignificant positive effect on FDI $(\beta=0.1415 ; p>0.10)$ under manufacturing sector, insignificant negative effect on FDI $(\beta=-0.0271 ; p>0.10)$ under agricultural sector, while having a significant negative effect on FDI at $1 \%$ statistical significance $(\beta=-0.2032 ; p<0.01)$ under construction sector; political stability has a significant negative effect on FDI at the 0.01 significant level $(\beta=-0.3318 ; p<0.01)$ under manufacturing sector. However, political stability has an insignificant negative impact on FDI under agricultural sector $(\beta=-0.0108 ; p>0.10)$ and construction sector $(\beta=-0.0163 ; p>0.10)$ as well. 


\section{Reliability Test}

The measures had a high reliability standard of 0.992 in line with the criterion that a Cronbach alpha coefficient of 0.60 is considered an average reliability while a coefficient of 0.70 or higher indicates that the instrument has a high reliability standard.

Table 8: Result of Reliability Test

\begin{tabular}{lllll}
\hline Scale Name & $\begin{array}{l}\text { No. of } \\
\text { Items }\end{array}$ & $\begin{array}{l}\text { Cronbach's } \\
\text { Alpha } \\
\text { Coefficient }\end{array}$ & $\begin{array}{l}\text { No. of items } \\
\text { dropped }\end{array}$ & $\begin{array}{l}\text { No. of items } \\
\text { retained for } \\
\text { main analysis }\end{array}$ \\
\hline Foreign Direct Investment & 10 & 0.992 & Nil & 10 \\
\hline
\end{tabular}

Source: Authors computation.

\section{CONCLUSION AND RECOMMENDATIONS}

The study arrived at the following conclusions; TI have a significant positive effect on FDI inflow into the Nigerian economy. Specifically, TH and 5CDE have significant positive effects on FDI inflows into the Nigerian economy. The significant positive effect of TI on FDI occurs fully under manufacturing and construction sector while having a partial significant effect under agriculture sector; thus, indicates poor administration of TI in Nigeria. Lastly, TI administration in Nigeria is not adequately and effectively carried out. Based on conclusion, the following recommendations are made; Nigerian government should maintain the elegant of TH alongside CDE and possibly device means of improving them because empirical evidence showed how US firm realized higher return on capital invested over and above European investment in home countries. Government should intensify means of ensuring that the impact of TI on FDI extends to agricultural sectors, so as to gain more value and continuously re-invest the profit with a view to enhancing the capital base of FDI inflow into the Nigerian economy.

\section{REFERENCES}

[1] Abubakar Z, Haruna M A, Ahmed B A (2012). The role of Nigerian investment promotion council in attracting FDI in Nigeria. European Scientific Journal, 8 (7), ISSN: 1857-7881 (Print) UDC:339.727.22 (662.6)

[2] Adeleke K M, Olowe S O, Fasesin O O (2014). Impact of FDI on Nigeria Economic Growth. International Journal of Academic Research in Business and Social Sciences, August 2014, 4 (8), ISSN: 2222-6990

[3] Agada G O, Okpe T J (2012). Determination of risks of foreign investment. Journal of economics and social research, 1 (2), $13-20$

[4] Aganga O O (2014). Nigeria’s manufacturing sector in 2012, Daily Independent, Lagos 9 (Monday, October 6, 2014)

[5] Agodo O (1978). The Determinants of US Private Manufacturing Investments in Africa. J Int Bus Stud 9, 95-106. DOI: 10.1057/palgrave.jibs.8490671

[6] Andabai P W (2014). Determinants of Public Policies and the Manufacturing Sector in Nigeria. An International Multidisciplinary Journal, Ethiopia 8 (1), 237-251

[7] Anyanwu J (2000). Why Does FDI Go Where It Goes?: New Evidence from African Countries, Annals of Economics and Finance 13 (2), 425-462

[8] Arogundade J A (2005). Nigerian income tax and its international dimension. Ibadan: Spectrum Books Limited

[9] Asiedu E (2002), Determinants of Foreign Direct Investment to Developing Countries: Is Africa Different, World Development, 30 (1), 107-19

[10] Babatunde K A, Adepeju S (2012). The impact of TI on FDI in the oil and gas sectors in Nigeria. IOIR Journal of Business and Management. 6 (1), 1-15

[11] Bora S M (2013). The Effectiveness of tax incentives in attracting foreign direct incentives to Ethiopia, being a master thesis submitted to the department of economics, international institute of social studies, The Hague, The Netherlands

[12] Dickson E O, Presley K O (2013). Tax incentives and revenue productivity of the Nigerian tax system. International Journal of Development and Economic Sustainability, 1 (1), 31-44

[13] Dinning H J, Lundan S M (2008). Institution and the OLI paradigm of MNE. Asia Pacific journal of management. 24 (4) 573-593. DOI: $10.1007 / \mathrm{s} 10490-007-9074-\mathrm{z}$ retrieved on 16, march 2020

[14] Dinning H J (2000). The eclectic paradigm as an envelope for economic and business theories of MNE activities. International Business Review. 2 (9) 163-190 retrieved on $16^{\text {th }}$ March 2020 at www.exetor.ac.uk

[15] Dipak M, Ata M (2003). The Africa Manufacturing Firm, an Analysis Based on the Firm Studies in Sub - Sahara Africa. Taylor and Francis Limited

[16] Ehijiele E, Sunday A, Nuruddeen L (2016), Foreign direct investment and its effect on the manufacturing sector in Nigeria. International Journal of Scientific and Research Publications, Vol 6, Issue 5, ISSN 2250-3153

[17] Ezera M (2016). Customs duty incentives and their effects on customs revenue mobilization: the case of Zimbabwe (20092014). Public and Municipal Finance, 5 (1), 6-13. DOI: 10.21511/pmf.05(1).2016.01

[18] Fletcher K (2002). Tax Incentives in Cambodia, Lao PDR, and Vietnam. IMF Conference on Foreign Direct Investment

[19] George T P, Bariyima D K (2015). Tax Incentives and Foreign Direct Investment in Nigeria. IOSR Journal of Economics and Finance (IOSR-JEF) e-ISSN: 2321-5933, p-ISSN: 2321-5925, 6 (5), 10-20 www.iosrjournals.org

[20] Hassett K A, Hubbard R G (2002), Tax policy and business investment. Handbook of Public Economics, vol 3, Elsevier

[21] Ifueko O O (2011). Emerging Issues In Tax Administration: The Way Forward Being a Lecture delivered at the $4^{\text {th }}$ National Conference Of The Dept. of Finance, Faculty of Business Administration, University Of Lagos on July $12^{\text {th }}, 2011$

[22] Lall (2002). Foreign investment transactional and development countries, Macmillan Press Ltd, London 
[23] Macaulay E D (2011). Foreign direct investment and the performance of the Nigerian economy. Proceedings of the $1^{\text {st }}$ International Technology, Education and Environment Conference, 629-633

[24] Michael Kransdorff (2010). Tax incentive on Foreign Direct Investment in south Africa. Consilience: The journal for sustainable development. Vol. 3

[25] Milli T J, Azime A H, Gollagori R (2016). The Relationship between FDI flows and Tax Revenues in Ethiopia: an Evidence based on ARDL Model with a Structural Break. International conference on Ethiopian, 21-23

[26] Morisset J, Pirnia N (1999). How Tax Policy and Incentives Affect Foreign Direct Investment: A Review. Retrieved on July 20, 2012 from http://www.rru.worldbank.org.documents

[27] Morisset J (2003). Using tax incentives to attract Foreign Investment, The World Bank Group, Private Sector and Infrastructure Network, available on http://rru.worlgbank.org/viewpoint/index.asp

[28] Morisset J, Pirnia N (2000). How tax policy and incentives affect foreign direct investment: A review, Foreign Investment Advisory Service (FIAS)

[29] Nwankwo O G, Ademola O, Kehinde O (2013). Effects Of Globalization On Foreign Direct Investment In Nigeria. Lorem Journal of Business and Economics (LJBE) 1 (1), 11-17

[30] Olaleye M O, Riro G K, Memba F S (2016). Effect of reduced company income tax incentives on foreign direct investment in listed Nigerian manufacturing companies. European Journal of Business, Economics and Accountancy, 4 (1), $39-54$

[31] Olopoenia R A (1985). Foreign investment and the growth rate of capital import countries. A Technical note. The Nigerian Journal of Economic and social studies, Vol 26, No 2

[32] Oloyede J A (2002), Principles of International Finance, Forthright Educational Publishers, Lagos

[33] Omankhanlen A E (2011). The Effect of Exchange Rate and Inflation on Foreign Direct Investment and Its Relationship with Economic Growth in Nigeria. Economics and Applied Informatics, Dunarea de Jos University of Galati, issue 1, pages $5-16$

[34] Ondabu I T, Willy M, Kisaka E S (2016). Effects of tax incentives on performance of listed firms in Kenya International Journal of Scientific and Research Publications, volume 6, issue 7, July 2016, 678, ISSN 2250-3153

[35] Otepola A (2002). FDI as a Factor of Economic Growth in Nigeria. Dakar, Senega. African Institute for Economic Development and Planning (IDEP), May. Available online at: idep@unidep.org, http://www.unidep.org

[36] Soludo C C (2003). Debt Poverty and Inequality, Okonjo-Iweala, Soludo and Mulitar (Eds), the Debt Trap in Nigeria, Africa World Press NJ, 23-74

[37] Sulaiman L A, Azeez B A (2012). Effect of External Debt on Economic Growth of Nigeria. Journal of Economics and Sustainable Development, ISSN 2222-1700 (Paper), Vol. 3, No. 8, 71

[38] Tea Kbiltsetskhlashvili (2010). Attracting Investors: Case of Impact of FDI on the Achievements of Economic Growth in Georgia. IBSU Scientific Journal, 4 (2), 35-51

[39] Thiess B, Georg W (2006). The Impact of Non-Profit Taxes on Foreign Direct Investment: Evidence from German Multinationals

[40] Uwubanmwen A E, Ogiemudia O A (2006). Foreign Direct Investment and Economic Growth: Evidence from Nigeria. International Journal of Business and Social Science, 7 (3), 89-103

[41] Vintila D (2010). foreign Direct investment theories : an overview of the main FDI theories. Vol 2 (2), pg 3 retrieved on www.ejist.ro on $12^{\text {th }}$ March 2020

[42] Walid Z S (2010). Determinants of direct foreign investment: Evidence from Jordan, Business and Economic Horizon, 1 (1) $67-75$

[43] Wells I, Allen N (2001).Tax Holidays to Attract Foreign Direct Investment: Lessons from Two Experiments, FIAS, Using Tax Incentive to compete for Foreign Direct Investment, Occasional paper No. 15

[44] The World Bank annual report 1996 (English). Washington DC; World Bank. http://documents.worldbank.org/curated/en/357461468137379235/The-World-Bank-annual-report-1996

[45] Zee H, Stotsky J G, Ley E, (2002). Tax Incentives for Business Investment: A Primer for Policy Makers in Developing Countries, World Development, 30 (9), 1497-1516 